\title{
REIT Conversions
}

\author{
Olgun Fuat Sahin \\ Saint Louis University
}

In this study, I examine the wealth effects of REIT conversions. I find that REIT conversion announcements create significant positive wealth for shareholders of firms announcing REIT conversions. I find that cumulative average abnormal return around REIT conversion announcements is 6.01 percent. The wealth gain is 7.63 percent for those firms planning to convert into REITs through spinoffs. The results also show that shareholder wealth gains are associated with potential tax savings.

\section{INTRODUCTION}

In this study, I examine shareholder wealth effects of REIT conversion announcements. These conversion announcements became more common following recent IRS rulings that expanded definition of real estate. It is no surprise that firms wishing to unlock more shareholder wealth turn to REIT conversions provided that the expansion of real property definition by recent IRS rulings would provide the support for REIT qualification.

A Real Estate Investment Trust (REIT) is a qualifying pass-through entity under the Real Estate Investment Trust Act of 1960. REITs are formed similar to closed-end investment companies that invest in real estate properties and mortgages. REITs can avoid paying corporate income taxes if they meet certain requirements; however, the income that is distributed to shareholders is taxed at the individual level. REIT requirements are:

- At least 75 percent of the assets must consist of real estate assets,

- At least 75 percent of income must be derived from rents, mortgages, and gains from real estate sales,

- At least 90 percent of the taxable income must be distributed to shareholders each year.

It is clear that the definition of real estate in REIT qualification is very important. The 1960 Act allows IRS to decide what constitutes as real estate in determining REIT qualification. As the economy evolves, it becomes necessary to seek guidance from IRS as to what constitutes as real estate. For example, the 1960 Act could not foresee cell phone towers as real estate. In its recent rulings, IRS broadened the real estate base that could be owned by an entity qualifying as a REIT. These rulings came as a result of firms planning to convert into REITs and include cell phone towers and outdoor advertising structures.

There was a notable increase in the number of REIT conversion announcements after 2009. In fact, I identified 26 conversion announcements after 2009, of which 18 were completed successfully, 6 were pending, and 2 failed to materialize in conversions as of the end of 2015. 
REIT conversion is a loose term that covers a broad range of corporate restructuring transactions. In this paper, I define a REIT conversion as a reorganization transaction leading to at least one surviving firm qualifying as a REIT. There are essentially four different types of REIT conversions:

- A spinoff that qualifies as a REIT in which parent firm survives as an independent firm. Cincinnati Bell, Inc. spun off CyrusOne Inc., a wholly owned subsidiary, into a publicly traded REIT. CyrusOne Inc. owns and operates data centers.

- A publicly held corporation seeks to qualify as a REIT. I call this a direct conversion. American Tower Corporation, developer and owner of cell phone towers, went through a process in which it applied for a private letter ruling from IRS to establish its assets would qualify as real estate. American Tower Corporation created a wholly owned subsidiary, America Tower REIT, Inc., and merged with it to complete its conversion into a REIT.

- A corporation acquires/merges with a REIT to transfer its assets into a REIT structure. American Home Mortgage, Inc. acquired Apex Mortgage Capital, Inc., a firm structured as a REIT.

- A splitting of a firm into an operating and a qualifying REIT forms. Penn National Gaming Inc. completed splitting of its real-estate holdings into a new REIT called Gaming and Leisure Properties Inc. Following the spin-off, Gaming and Leisure Properties leased the real property back to Penn National Gaming, which continued its gaming business. It is important to note that the difference between a spinoff and a split is about the scope of new REIT's business. In a spinoff, a REIT may have many customers other than the parent firm. However, in a split, the primary business of the REIT would involve the parent company.

A true REIT conversion occurs if the transaction is structured as in the second type, however it is common to generalize all 4 types of transactions as REIT conversions.

The main reason that a firm would pursue a REIT conversion is to reduce or avoid its tax liability. However, there are other potential advantages of becoming a REIT. Those include: increasing transparency and focus of a firm leading to better valuation of its assets through a conversion, and meeting the demand of those investors who are willing to pay a premium for the income generated through substantial dividend payments.

An important disadvantage of qualifying as a REIT is that the required payout limits the ability of a REIT to retain internally generated profits for reinvestment purposes, reducing its growth potential. However, it is difficult to determine if a conversion signals information about growth prospects or lack of them. In addition, if access to capital at a low cost remains available then a conversion should not limit ability of a firm to continue investing in those profitable opportunities. In this scenario, a REIT conversion would have no negative effects.

I use a sample of 38 REIT conversion announcements between 1991 and 2015 to examine the wealth effects around the announcements. Results show that there is a significant shareholder wealth gain around the announcement of REIT conversions. The cumulative average abnormal return to firms announcing REIT conversion is 6.01 percent. I further examine the sources of wealth gains and find support for the tax based explanation.

The rest of the paper is organized as follows. The next section reviews limited literature on REIT conversions followed by the section that describes the data and methodology used in measuring wealth effects of REIT conversions. The results section reports findings on wealth effects of REIT conversions. The following two sections examine the sources of wealth gains in REIT announcements and tax policy implications. Finally, the last section concludes the paper.

\section{LITERATURE REVIEW}

In this section I review literature on REIT conversions and develop a hypothesis related to effects of conversions on shareholders' wealth. Unfortunately, I did not find extensive research on REIT conversion. The literature review covers research related to value of qualifying as a REIT and what can be found on REIT conversions. 
Gyourko and Sinai (1999) estimate the impact of REIT structure on the market value of REITs based on data from 1997. Gyourko and Sinai (1999) find that REIT structure adds $2 \%-5 \%$ to aggregate market capitalization of REITs. The value addition of the REIT structure is higher for those firms with lower payout ratios. Gyourko and Sinai (1999) suggest that the value of REIT structure would increase in the future as REITs attract an ownership clientele that can avoid taxes on distributions they receive from REITs.

Sun, Rahman and Munn (2013) examine four types of changes in timberland ownership between 1997 and 2010, including 5 REIT conversions. Sun, Rahman and Munn (2013) find that cumulative average abnormal return in REIT conversions is 6.45 percent over event days $(-1,+1)$ around the announcement date. They do not investigate sources of these gains.

Results of Gyourko and Sinai (1999) and Sun, Rahman and Munn (2013) suggest that there may be a wealth gains around the announcements of REIT conversions. Therefore, I first test the following hypothesis:

- REIT conversions do not create wealth for shareholders regardless of its type.

Rejection of the test hypothesis would lead to further analysis of sources of shareholder wealth effects.

\section{DATA AND METHODOLOGY}

I search for Lexis-Nexis collections to identify conversion announcements by publicly owned firms between 1990 and 2015. I identify 38 such announcements. I report the main characteristics of sample announcement in Table 1.

\section{TABLE 1 \\ SAMPLE CHARACTERISTICS}

This table reports REIT conversion announcements and their characteristics in terms of completion, type of conversion proposal, and annual frequency of announcements. The sample of observations is based searching Lexis-Nexis database for REIT conversion announcements between 1990 and 2015. I identify 38 such announcements. The Panel A reports number of completed, failed and pending REIT conversions. A failed announcement is one that the firm has provided information that it is no longer pursuing a conversion. A conversion announcement not yet complete as of the end of 2015 is labeled as pending. Panel B reports the types of conversions. A spin-off refers to a conversion in which a parent firm spins of a subsidiary into a REIT. Other types of conversions include direct conversions, mergers and splits.

\begin{tabular}{lcc}
\hline \multicolumn{2}{l}{ Panel A. Status of REIT conversion announcements as of December 2015.} \\
\hline Status & Frequency & Percent \\
\hline Completed & 28 & 73.68 \\
Failed & 4 & 10.53 \\
Pending & 6 & 15.79 \\
\hline Total & 38 & 100.00 \\
\hline Panel B. Types of REIT conversion announcements. & \\
\hline Type & Frequency & Percent \\
\hline Spin-off & 15 & 39.47 \\
Other & 23 & 60.53 \\
\hline Total & 38 & 100.00 \\
\hline
\end{tabular}

The Panel A of Table 1 reports number of completed, failed and pending REIT conversions. A failed announcement is one that the firm has provided information that it is no longer pursuing a conversion. I find that about 11 percent of conversion announcements end in failure in this sample. A conversion announcement not yet complete as of the end of 2015 is labeled as pending. There were 6 conversion 
announcements or about 16 percent of all announcements in the sample that were not complete as of December 2015. Panel B of Table 1 reports the types of conversions. A spin-off refers to a conversion in which a parent firm spins of a subsidiary into a REIT. Other types of conversions include direct conversions, mergers and splits. I identified that 15 conversion announcements in the sample were structured as spin-offs. Most (26) conversion announcements took place after 2009.

I use a standard market model to analyze stock return behavior around the announcements of REIT conversions. Details of the market model are not presented in the paper; however, they are available upon request. I estimate the parameters of market model for each announcements based on daily returns over trading days $(-250,-10)$ relative to the event day. I use the approach developed by Boehmer, Poulsen, and Musumeci (1991) to test the significance of cumulative average abnormal return (CAAR) over three days $(-1,+1)$ around conversion announcements.

\section{RESULTS}

I show the stock return behavior around conversion announcement in Table 2.

TABLE 2

CUMULATIVE AVERAGE ABNORMAL RETURNS (CAAR)

This table reports cumulative average abnormal returns (CAAR) around announcements of REIT conversions. The sample of observations is based searching LexisNexis database for REIT conversion announcements between 1990 and 2015. I identify 38 such announcements. Anel A reports cumulative average abnormal returns over event days $(-10,+10)$ around announcements based on the market model. A spinoff refers to a conversion in which a parent firm spins of a subsidiary into a REIT. Other types of conversions include direct conversions, mergers and splits. Panel B provides cumulative average abnormal returns over a 3 -day $(-1,+1)$ event period around conversion announcements.

\begin{tabular}{crrr}
\hline \multicolumn{2}{l}{ Panel A. Cumulative average abnormal returns } & & \\
\hline Relative event day & All firms & Spin-off & Other \\
\hline-10 & 0.0012 & 0.0061 & -0.0021 \\
-9 & 0.0015 & 0.0112 & -0.0049 \\
-8 & -0.0023 & 0.0058 & -0.0076 \\
-7 & -0.0054 & -0.0031 & -0.0069 \\
-6 & -0.0092 & -0.0152 & -0.0052 \\
-5 & -0.0035 & 0.0035 & -0.0081 \\
-4 & 0.0008 & 0.0132 & -0.0072 \\
-3 & 0.0084 & 0.0305 & -0.0061 \\
-2 & 0.0086 & 0.0264 & -0.0029 \\
-1 & 0.0123 & 0.0289 & 0.0015 \\
0 & 0.0465 & 0.0917 & 0.0171 \\
1 & 0.0688 & 0.1027 & 0.0466 \\
2 & 0.0628 & 0.1001 & 0.0384 \\
3 & 0.0638 & 0.1090 & 0.0344 \\
4 & 0.0637 & 0.1124 & 0.0320 \\
5 & 0.0627 & 0.1160 & 0.0278 \\
6 & 0.0618 & 0.1177 & 0.0253 \\
7 & 0.0597 & 0.1177 & 0.0219 \\
8 & 0.0620 & 0.1229 & 0.0224 \\
9 & 0.0607 & 0.1260 & 0.0181 \\
10 & 0.0633 & 0.1263 & 0.0222 \\
\hline
\end{tabular}




\begin{tabular}{lrrr}
\hline \multicolumn{4}{l}{ Panel B. Cumulative average abnormal returns over event days $(-1,+1)$} \\
\hline Variable & All firms & Spin-off & Other \\
\hline CAAR & 0.0601 & 0.0763 & 0.0496 \\
T-statistic & 4.46 & 2.67 & 4.02 \\
P-value & 0.00 & 0.02 & 0.00 \\
\hline
\end{tabular}

Panel A of Table 2 reports daily abnormal returns for all firms, spin-offs and others over event days ($10,+10)$ around conversion announcements. Results show that there are significant positive abnormal returns to shareholders around REIT conversion announcements. Results also indicate that shareholder wealth gains are stronger for conversions involving spin-offs. Panel B of Table 2 reports cumulative average abnormal returns over event days $(-1,+1)$ around conversion announcements. CAARs are 6.01 percent, 7.63 percent, and 4.96 percent for all announcements, spin-offs, and others, respectively. These CAARs are all statistically significant at 5 percent level. I report cumulative abnormal return from 10 days before to 10 after conversion announcements in Figure 1. The results clearly show that shareholder gains around conversion announcements remain persistent.

FIGURE 1

CUMULATIVE AVERAGE ABNORMAL RETURNS

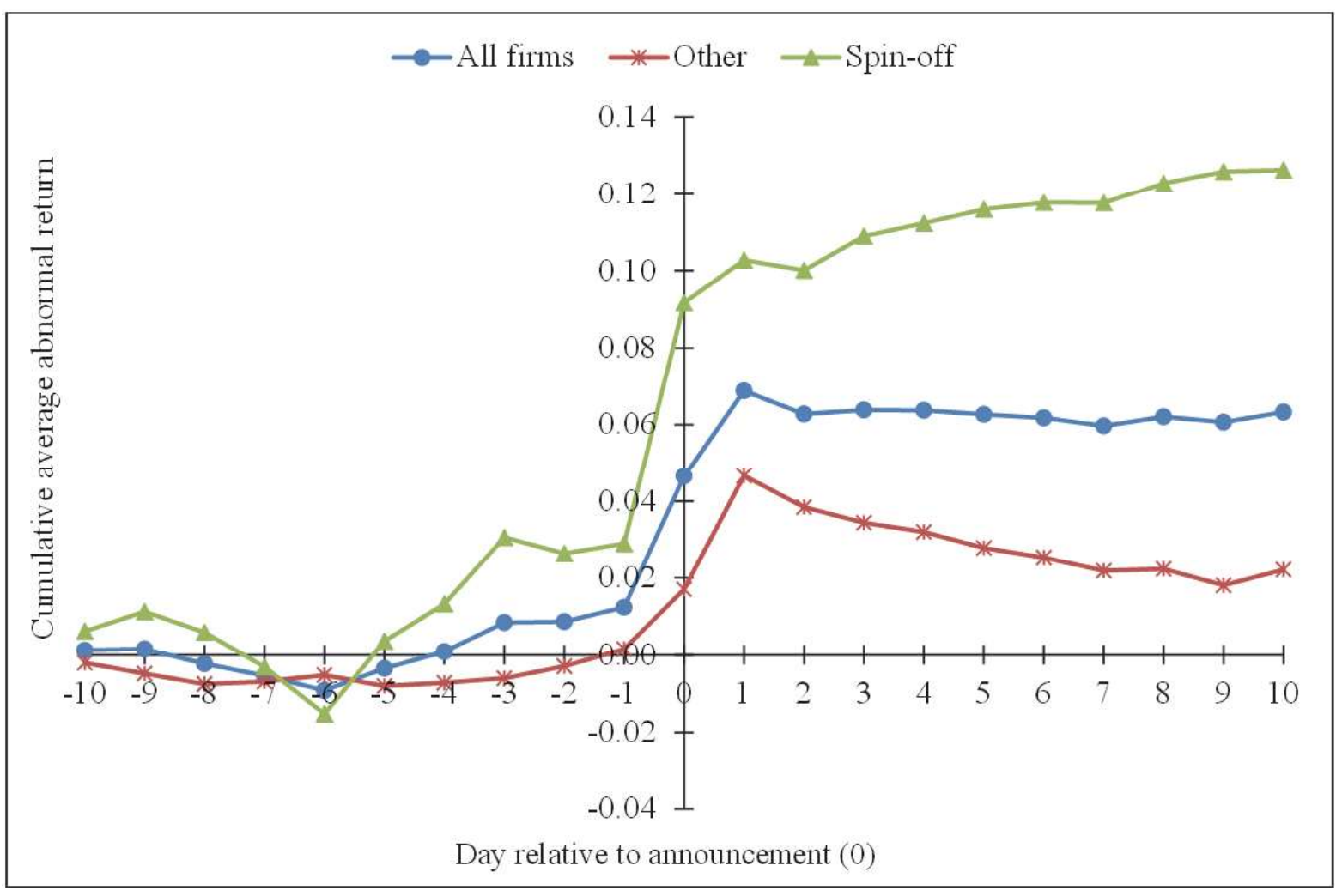

The evidence in Table 2 and Figure 1 indicate that REIT conversion announcement are associated with shareholder wealth gains. Given this evidence, I then turn to possible sources of gains from conversion announcements. 


\section{SOURCES OF WEALTH GAINS}

In this section, I attempt to identify sources of shareholder wealth gains around conversion announcements. One of the attractions of qualifying as a REIT is that it will allow a firm to avoid corporate income taxes as suggested by Gyourko and Sinai (1999). However, Riano (2015) and Borden (2015) argue that tax savings associated with REIT conversions may be overstated. Their argument is about the higher payout that REITs would have to maintain to continue qualifying as a REIT. The higher payout ratio would increase the tax burden of shareholders who pay tax on REIT distributions. According to Gyourko and Sinai (1999), it is reasonable to expect an increased tax burden on shareholders of REITs due to high distributions. However, Gyourko and Sinai (1999) suggest that ownership clientele of REITs would change, so that tax exempt or low tax investors would invest in REITs. If this is true, it casts doubt on the argument of Riano (2015) and Borden (2015) that tax benefits of conversions is not as significant. I address effects of taxes on REIT conversions, however, I do have sufficient data to test change in ownership composition.

An important disadvantage of qualifying as a REIT is that the required payout ratio limits the ability of a REIT to retain internally generated profits for reinvestment purposes reducing its growth potential. However, it is difficult to determine if a conversion signals information about growth prospects or lack of them. In addition, if access to capital at a low cost remains available then a conversion should not limit ability of a firm to continue investing in those profitable opportunities. In this scenario, a REIT conversion would have no negative effects.

The overall market environment may also have an effect on REIT conversions. For example, there may be an excess demand for yields as it has been the case since the financial crisis in 2008. REIT conversions may be a response to meet this excess demand. The fact that there were 26 REIT conversion announcements after 2009 lends support to this argument.

I use multivariate analysis to examine the effects of variables related to taxation, financial flexibility, growth potential and market environment on cumulative abnormal returns around REIT conversion announcements. The description of the variables and Compustat pneumonic are shown below.

\begin{tabular}{|c|c|}
\hline ETR & $\begin{array}{l}\text { ETR is the book effective tax rate and computed as total tax } \\
\text { expense (TXT) divided by pretax book income less special items } \\
\text { (PI - SPI). }\end{array}$ \\
\hline Cash ratio & $\begin{array}{l}\text { Cash ratio is cash and short-term investments (CHE) divided by } \\
\text { book value of assets (AT). . }\end{array}$ \\
\hline Leverage & $\begin{array}{l}\text { Leverage is the sum of total long term debt (DLTT) and total debt } \\
\text { in current liabilities (DLC) divided by book value of assets (AT). }\end{array}$ \\
\hline Z-score & $\begin{array}{l}\text { Z-score is } 3.3 \times(\mathrm{OIADP} / \mathrm{AT})+1.2 \times(\mathrm{ACT}-\mathrm{LCT}) / \mathrm{AT}+(\mathrm{SALE} \\
/ \mathrm{AT})+0.6 \times(\mathrm{PRCC} \text { F } \times \text { CSHO }) /(\mathrm{DLTT}+\mathrm{DLC})+1.4 \times(\mathrm{RE} / \\
\mathrm{AT}) \text {. OIADP is operating income after depreciation. ACT is total } \\
\text { current assets. LCT is total current liabilities. SALE is net sales. } \\
\text { PRCC_F is the market price of common stock at the end fiscal year. } \\
\text { CSHO is common shares outstanding. RE is retained earnings. }\end{array}$ \\
\hline Size & $\begin{array}{l}\text { Size is the market value of equity and computed as PRCC_F } \times \\
\text { CSHO. }\end{array}$ \\
\hline Book-to-market & $\begin{array}{l}\text { Book-to-market is [(Book value of assets }- \text { Book value of equity })+ \\
\text { Market value of equity] / Book value of assets or [(AT - CEQ })+ \\
(\mathrm{PRCC} F \times \mathrm{CSHO})] / \text { AT. }\end{array}$ \\
\hline REIT Index yield & $\begin{array}{l}\text { This is the yield of the NAREIT REIT Index dividend yield the } \\
\text { month before the announcement. The REIT Index is represented by } \\
\text { the FTSE NAREIT all REIT Index and historical yields are } \\
\text { available at https://www.reit.com/. }\end{array}$ \\
\hline
\end{tabular}




\begin{tabular}{|l|l|}
\hline S\&P 500 Index yield & $\begin{array}{l}\text { This is the yield of the S\&P 500 Index dividend yield the month } \\
\text { before the announcement. The S\&P 500 Index yields are based on } \\
\text { data from Robert Shiller available at } \\
\text { http://www.econ.yale.edu/ } \sim \text { shiller/data.htm. }\end{array}$ \\
\hline 10-year Treasury yield & $\begin{array}{l}\text { This is the yield of the } 10 \text {-year Treasury securities the month before } \\
\text { the announcement. The 10-year Treasury yield data is obtained } \\
\text { from FRED at https://research.stlouisfed.org/fred2. }\end{array}$ \\
\hline
\end{tabular}

I follow Kubick, Lynch, Mayberry, and Omer (2014) in computing ETR and Size. Computations of cash ratio, leverage, Z-score, and book-to-market are based on Daniel, Denis, and Naveen (2010).

I report the descriptive statistics of variables used in an ordinary least squares regressions in Table 3. I note that ETR, cash ratio, and Z-score have potentially significant departures from the normal distribution as evidenced by the relative values of averages and medians. The average ETR is 18.9 percent while the median is at 34.4 percent. The average financial leverage is about $50 \%$. The median Z-score of the sample indicates financial distress. The median market value of sample firms is about $\$ 7.5$ billion.

TABLE 3

\section{DESCRIPTIVE STATISTICS}

This table reports descriptive statistics used in the analysis. The sample of observations is based searching LexisNexis database for REIT conversion announcements between 1990 and 2015. I identify 38 such announcements. ETR, Leverage, Cash ratio, Z-Score, Size and Book-to-Market are based on Compustat data for the fiscal year before a conversion announcement. Descriptions of these variables and how they are computed using Compustat pneumonic (in parentheses) are as follows. ETR is the book effective tax rate and computed as total tax expense (TXT) divided by pretax book income less special items (PI - SPI). Leverage is the sum of total long term debt (DLTT) and total debt in current liabilities (DLC) divided by book value of assets (AT). Cash ratio is cash and short-term investments (CHE) divided by book value of assets (AT). Z-score is $3.3 \times$ $(\mathrm{OIADP} / \mathrm{AT})+1.2 \times(\mathrm{ACT}-\mathrm{LCT}) / \mathrm{AT}+(\mathrm{SALE} / \mathrm{AT})+0.6 \times\left(\mathrm{PRCC} \_\mathrm{F} \times \mathrm{CSHO}\right) /(\mathrm{DLTT}+$ $\mathrm{DLC})+1.4 \times(\mathrm{RE} / \mathrm{AT})$. OIADP is operating income after depreciation. ACT is total current assets. LCT is total current liabilities. SALE is net sales. PRCC_F is the market price of common stock at the end fiscal year. CSHO is common shares outstanding. RE is retained earnings. Size is the market value of equity and computed as PRCC_F $\times$ CSHO $\times 1,000,000$. Book-to-market is [(Book value of assets - Book value of equity $)+$ Market value of equity] / Book value of assets or $\left[(\mathrm{AT}-\mathrm{CEQ})+\left(\mathrm{PRCC} \_\mathrm{F} \times \mathrm{CSHO}\right)\right] / \mathrm{AT}$.

\begin{tabular}{lrrrrrr}
\hline Variable & Average & Median & Minimum & Maximum & Deviation & $\mathrm{N}$ \\
\hline ETR & 0.1885 & 0.3436 & -3.8905 & 0.7683 & 0.7127 & 37 \\
Leverage & 0.4946 & 0.4947 & 0.0000 & 0.9333 & 0.2189 & 37 \\
Cash ratio & 0.0568 & 0.0406 & 0.0000 & 0.1733 & 0.0453 & 37 \\
Z-score & 1.7347 & 1.3826 & -0.7109 & 4.8230 & 1.3222 & 35 \\
Size (in 000) & $7,414,118$ & $7,523,320$ & $3,096,708$ & $10,084,621$ & $1,544,298$ & 36 \\
Book-to-market & 0.7696 & 0.7752 & 0.3775 & 1.2481 & 0.1595 & 36 \\
\hline
\end{tabular}

I estimate six regression specifications and follow White (1980) heteroskedasticity adjustments. The results of these regression specifications are provided in Table 4. 


\section{TABLE 4 \\ RESULTS OF MULTIVARIATE ANALYSIS}

This table reports results of multivariate analysis of CAAR. The sample of observations is based searching LexisNexis database for REIT conversion announcements between 1990 and 2015. I identify 38 such announcements. ETR, Cash ratio, Leverage, Z-Score, Size and Book-to-Market are based on Compustat data for the fiscal year before a conversion announcement. Please see Table 3 for their descriptions are computations. Conversion is a dummy variable with a value of 1 if the type of conversion proposal is a spinoff, and 0 otherwise. The REIT Index, S\&P 500 Index and 10 year Treasury yields are measured as of the month before the announcement. The REIT Index is represented by the FTSE NAREIT all REIT Index and historical yields are available at https://www.reit.com/. The S\&P 500 Index yields are based on data from Robert Shiller available at http://www.econ.yale.edu/ shiller/data.htm. The 10-year Treasury yield data is obtained from FRED at https://research.stlouisfed.org/fred2.

\begin{tabular}{lrlrlrl}
\hline Variable & Model 1 & Model 2 & Model 3 & \\
\hline Intercept & 0.0722 & $* * *$ & 0.0919 & $* *$ & 0.0834 & $* * *$ \\
\hline ETR & 0.0563 & $* * *$ & 0.0539 & $* * *$ & 0.0579 & $* * *$ \\
\hline Cash ratio & -0.6531 & $* *$ & -0.6624 & $* *$ & -0.6352 & $* *$ \\
\hline Spinoff & 0.0452 & $*$ & 0.0452 & $*$ & 0.0466 & $*$ \\
\hline Leverage & & & -0.0372 & & & \\
\hline Z-score & & & & -0.0076 & \\
\hline Adjusted $\mathrm{R}^{2}$ & 0.2999 & 0.2854 & & 0.2920 & \\
\hline
\end{tabular}

\section{TABLE 4 \\ RESULTS OF MULTIVARIATE ANALYSIS (CONTINUED)}

This table reports results of multivariate analysis of CAAR. The sample of observations is based searching LexisNexis database for REIT conversion announcements between 1990 and 2015. I identify 38 such announcements. ETR, Cash ratio, Leverage, Z-Score, Size and Bookto-Market are based on Compustat data for the fiscal year before a conversion announcement. Please see Table 3 for their descriptions are computations. Conversion is a dummy variable with a value of 1 if the type of conversion proposal is a spinoff, and 0 otherwise. The REIT Index, S\&P 500 Index and 10 year Treasury yields are measured as of the month before the announcement. The REIT Index is represented by the FTSE NAREIT all REIT Index and historical yields are available at https://www.reit.com/. The S\&P 500 Index yields are based on data from Robert Shiller available at http://www.econ.yale.edu/ shiller/data.htm. The 10-year Treasury yield data is obtained from FRED at https://research.stlouisfed.org/fred2.

\begin{tabular}{|c|c|c|c|c|c|c|}
\hline Variable & Model 4 & & Model 5 & & Model 6 & \\
\hline Intercept & 0.0536 & & 0.0211 & & 0.1693 & \\
\hline ETR & 0.0556 & $* * *$ & 0.0574 & $* * *$ & 0.0513 & $* * *$ \\
\hline Cash ratio & -0.6709 & $* *$ & -0.6368 & $* *$ & -0.6059 & $* *$ \\
\hline Spinoff & 0.0433 & & 0.0462 & $*$ & 0.0353 & \\
\hline Leverage & & & & & -0.0477 & \\
\hline \multicolumn{7}{|l|}{ Z-score } \\
\hline Size & 0.0027 & & & & & \\
\hline Book-to-market & & & 0.0641 & & & \\
\hline REIT Index yield & & & & & -2.0357 & \\
\hline S\&P 500 Index yield & & & & & -1.1299 & \\
\hline 10-year Treasury yield & & & & & 1.6891 & \\
\hline Adjusted $\mathrm{R}^{2}$ & 0.2785 & & 0.2932 & & 0.2531 & \\
\hline
\end{tabular}


The dependent variable in these regression models is the firm level cumulative abnormal return over three days $(-1,+1)$ around the date of the announcement. The regression models explain about 30 percent of variability in cumulative abnormal returns. I observe that the results provide significant support to the tax based explanations of REIT conversions. A higher level of ETR is positively associated with firm level cumulative abnormal return around the announcement. Regression results also indicate that higher cash ratio is associated inversely with the cumulative abnormal return. This result does not support the argument that REIT conversions would reduce the financial flexibility. In addition, I find no significant effect of leverage, Z-score and book-to-market on cumulative abnormal returns. Even more interestingly, the results offer no evidence for REIT conversions driven by the market yield environment.

The results reported in Table 4 provide support for tax based explanation. In other words, I find that the announcement wealth gains are likely related to tax savings that REIT structure would create for their shareholders.

\section{TAX POLICY IMPLICATIONS}

In this section, I offer some scale to the wealth gains around REIT conversion announcements. I estimate the net present value of each announcement based on the product of market capitalization of a firm 2 days before the announcement and its cumulative abnormal return around the announcement. Then I convert the net present value of a REIT conversion to 2009 dollars using GDP deflator. I find that the aggregate net present value of all REIT conversion announcements is $\$ 7,494,709,351$. This estimate likely overstates the wealth gain because some conversion announcements did not succeed. The results suggest that the aggregate wealth gain may be at the expense of Treasury tax collections, which represents a wealth transfer from tax payers to shareholders of firms planning to convert into REITs.

\section{CONCLUSIONS}

In this study, I examine the wealth effects of REIT conversions and potential sources of wealth gains. I find that REIT conversions create significant wealth for shareholders of firms announcing REIT conversions. For example, on average three-day cumulative average abnormal return is 6.01 percent. It is higher for those firms planning to convert into REITs through spin-offs. The cumulative average abnormal return in that case is 7.63 percent. The results also show that the gains are related to potential tax savings associated with REIT conversions.

\section{REFERENCES}

Boehmer, E., Poulsen, A., \& Musumeci, J. (1991). Event study methodology under conditions of eventinduced variance. Journal of Financial Economics, 30(2), 253-272.

Borden, B. T. (2015). Reforming REIT taxation (or not), Houston Law Review, 53(1), 1-101.

Daniel, N. D., Denis, D. J., \& Naveen, L. (2010). Sources of financial flexibility: Evidence from cash flow shortfalls, working paper.

Gyourko, J., \& Sinai, T. (1999). The REIT vehicle: Its value today and in the future. Journal of Real Estate Research, 18(2), 355-275.

Kubick, T. R., Lynch, D. P., Mayberry, M. A., \& Omer, T. C. (2014). The effects of increased financial statement disclosure quality on tax avoidance: An examination of SEC comment letters, working paper.

Riano, K. (2015). President Eisenhower's 1956 prediction becomes a reality: The new art of the REIT spin. Available at SSRN: http://ssrn.com/abstract=2612223.

Sun, C., Rahman, M., \& Munn, I. A. (2013). Adjustment of stock prices and volatility to changes in industrial timberland ownership, Forest Policy and Economics, 26, 91-101.

White, H., (1980). A heteroscedasticity-consistent covariance matrix estimator and a direct test for heteroscedasticity. Econometrica, 48, 817-838. 